\title{
Rich or Modest - Analysis and Reconstruction of the Appearance of a Child's Coffin from 1779 from the Church of St. Nicholas in Gniew (Pomerania Province, Poland)
}

Introduction

Archaeological research carried out ${ }^{1}$ in 2013 in the Church of St. Nicholas in Gniew definitely broadened the knowledge of historians, art historians, and archaeologists of the material culture of the inhabitants of Royal Prussia. Much historical material was discovered in the church and the graveyard, including fragments of ceramic and glass dishes, textiles, archaeological wood, and metal artefacts, mostly represented by nails and devotional items (Grupa, Drążkowska 20ı 4; Grupa et al. 2014a; Grupa 2015; 2016; Grupa et al. 2015; 2016a; 2016b; Grupa, Warecka 2018; Michalik 20I8a; 20I8b). The researchers managed to identify, to a large extent, outlines of grave pits and, in some cases, to excavate remains of wooden coffins. In most research projects, teams register the existence of coffins and, possibly, describe their cross-sections, but this is the end of their analysis. In Gniew, archaeologists

I The work was carried out by a research team consisting of MA and PhD students under the supervision of Dr hab. Małgorzata Grupa, Professor of Nicolaus Copernicus University from the Institute of Archaeology of Nicolaus Copernicus University in Torun. 
took samples for dendrological analysis, which was carried out in the Laboratory of Monument Documentation and Conservation of the Nicolaus Copernicus University in Torun (Michalik 2018a). There was ample material from earlier seasons (2009-20I2). Each research season brought about new interesting findings including artificial flowers made of silk, paper, and metal wires (Grupa 20I5: 48-51; Grupa et al. 2015; 2016a; 2016b; Grupa, Nowak 2017: 160-168; Majorek, Grupa 2014, 335-347; 2016: 165-172) as well as metal decorations of a bonnet and a child's grave dress made of metal plates of silver-plated copper alloy (Grupa, Łukaszewicz 2019: I 40-152). It was similar in 2013, when each burial was analysed in detail on site (if possible), while other activities were performed in a laboratory. One of the most interesting findings was a child's coffin decorated with artificial flowers placed on the outside, in the corners and in the middle.

The aim of the work was to collect and describe the results of various examinations performed in relation to the child's coffin mentioned. It was unique on account of the fact that it was the first such detailed research including fabric analysis, identification of the taxon of the wood the coffin was made of, the structure and description of nails and artificial flowers. The final result of the above analyses was a drawing reconstructing the probable appearance of the coffin.

\section{Funeral ceremonies in modern Poland}

Both old and young people were buried ceremoniously in the church, in a crypt, on in the graveyard. In most cases, preparing the dead for their last road was the responsibility of the family. Customs differed, however, it was mostly about a worthy burial that would reflect the social status of the dead person and their family. In the Baroque, the wealthy dead were given lavish ceremonies that nearly turned into theatrical plays called pompa funebris. The whole ceremonial included a great number of actions: suitable for the occasion preparation of the house, both inside and on the outside walls, preparation of the body including make-up, preparation of grave clothes and a coffin, and then a whole series of prayers and singing during a vigil, an adequate number of mourners, and written invitations to the funeral delivered by the so-called funeral bidders. If the person died away from the planned burial place, the body was transported in a large funeral procession to the designated church. Sometimes, it would take a day, a few days, or even a month, depending on the distance and the programme of funeral services in different churches. In the church, castrum doloris was usually prepared, the basis of which was a catafalque decorated with fabrics, flowers and a large number of candles in candle holders ${ }^{2}$.

2 In most cases, it can be presumed that the person made some arrangements with their family with regard to the funeral ceremony, and sometimes they would even leave 
People sang and prayed both during the day and at night, then a funeral service was held (usually in the evening), a remedy cheering people's hearts, and then the person was buried in a crypt, under the church floor, or in the graveyard. All these activities considerably increased the cost of the funeral ceremony and, depending on their scale, their prices differed (Chrościcki 1974: 34-38; Kizik 1998: 18, 72, 85, I81; Grupa 2005: 28-35; Grupa et al. 2014b: 23-26).

What ultimately remained after each funeral ceremony were the remains and the coffin, buried in a grave or in a crypt, and their relics are now discovered by archaeologists. The body was usually put in a coffin in the shape of a flat or trapezium box with all kinds of decorations. It was upholstered with cloth - silk, linen, wool - sometimes even in two layers - linen and wool or linen and silk. Cheaper boxes were only painted. They were plain or with ornaments, sometimes imitating silk. There were also tapes on the coffin edge, attached to the coffin with studs along with the fabric. The studs did not only serve as structural elements but also as carriers of information, as they were used to form dates and inscriptions on the coffin lid. Apart from that, boxes were decorated with garlands or bunches of both real and artificial flowers (with the latter only found by archaeologists on coffins from the nineteenth century). The last decoration was a coffin portrait, a unique element in the Polish funeral culture (Chrościcki 1974: 54, 57; Dziubkowa 1993: 35; Grupa 2005: 32, 59-61, 87, 100-10I; Majorek, Grupa 2013: 70-71, 80).

\section{The coffin's description and location}

Coffin no. 3 with artificial flowers was located in excavation no. $5 / 13$. The excavation was made in the central nave of the church between the first pillar and the chancel, from the north (Fig. I). The grave pit was in the shape of a trapezium, along the W-E axis. Unfortunately, it was impossible to uncover it completely as part of it was located in the northern section of the excavation, and disturbing this structure posed a risk of wall collapsing. It was similar in the case of the coffin, the whole length of which but not the whole width was uncovered (Fig. 2), which is why its exploration was very difficult. However, even this partial uncovering of the coffin revealed artificial flowers in the corners. There were also lots of metal studs on the boards. The coffin was $110 \mathrm{~cm}$ long and its maximum width at the head end was $42 \mathrm{~cm}$, while at the feet end $-33 \mathrm{~cm}$. The thickness of the coffin boards was approx. $2 \mathrm{~cm}$. It is possible that the coffin used to have turned 'legs', approx. $3.5 \mathrm{~cm}$ in diameters, which were captured as wooden remains forming impressions in clay. On the eastern side of the lid (the narrowest part), a date made of studs could be seen - 1779 (Fig. 3).

written instructions in their last will (Grupa 2005: 30; Nowosad, Kowalkowski 20I6: 334; Klint et al. 2018: 340, 482-483). 


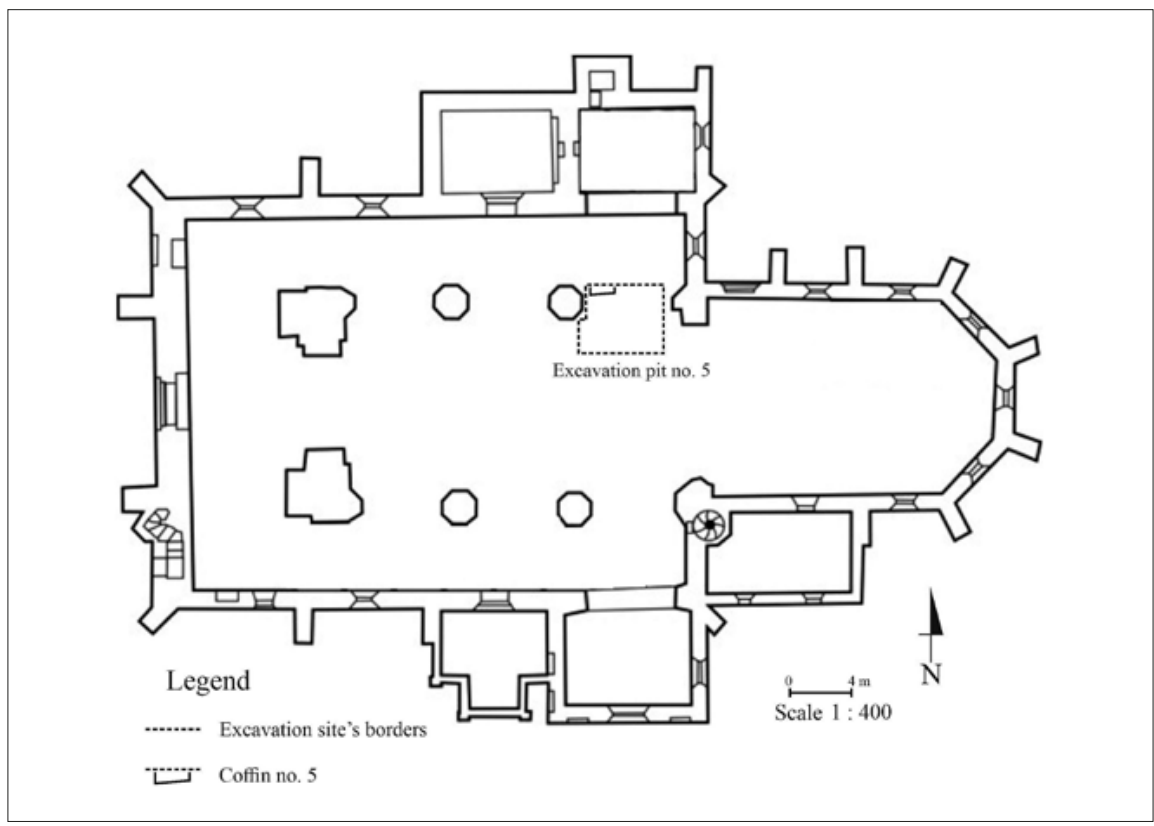

Fig. 1. The layout of the Church of St. Nicholas, with the location of the $5 / 13$ excavation (prepared by J. Michalik, the layout as published in: Grupa et al. 20I5, p. I2, Fig. 2).

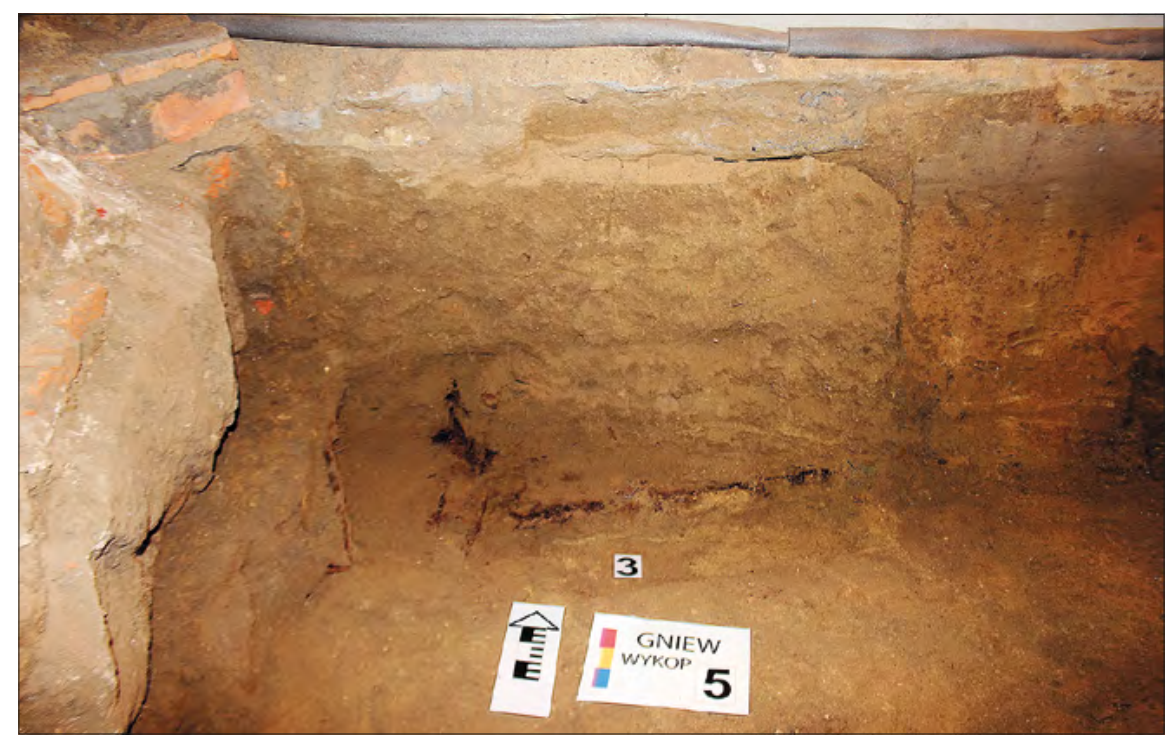

Fig. 2. A photograph of the $\mathrm{N}$ profile, with a visible outline of coffin no. 3 (photograph by D. Grupa). 
A child's skeleton was considerably mineralised. Due to contact with the ground, the bones became very brittle, and a large part of them was only seen as white impressions in the clay layer. Thus, anthropological examination was very limited. The partially preserved skull allowed to say it was a child. It was the second evidence for that, as the length of the coffin indicated a child's burial. Inside the coffin, apart from the skull bones and traces of decomposed skeleton bones, no grave goods were found. It can be assumed that they had completely decomposed. Thus, only the well-preserved flowers and studs on the coffin were analysed.

\section{Analysis of wood from the coffin}

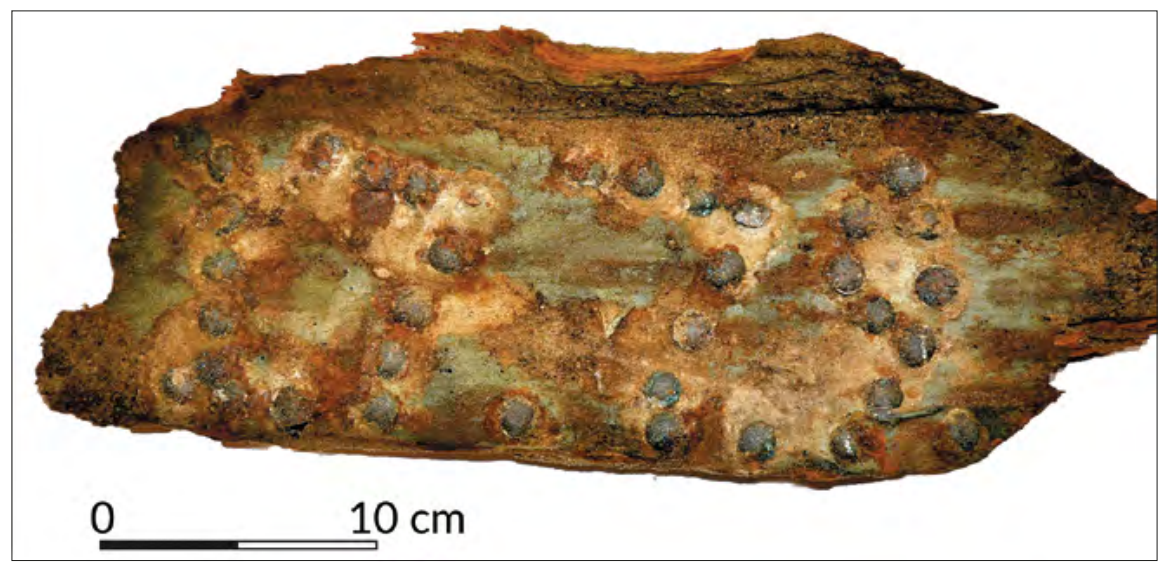

Fig. 3. The top of coffin no. 3, with the date 'I779' (photograph by D. Grupa).

Archaeological wood is a material that is only preserved in specific conditions. It quickly degrades in changing environmental conditions, so it is very rarely found in the accumulations discovered by archaeologists. In the case described, wood spent approximately 200 years in relatively stable humidity and temperature, which created and stabilised anaerobic conditions. This was an appropriate environment that preserved at least some elements of the burial (Grupa 2014: 299). The structure of the wood was considerably weakened, so it was difficult to take out the side with the burial date but ultimately, the whole of it was excavated (Fig. 3) and proper samples were taken.

Due to the fact that the wood structure during its deposition in clay was partially decomposed, samples needed to be adequately prepared in order to properly determine the wood taxon. Each sample collected was first soaked in water and then cut to obtain 'slices' with preserved structures of wood tissues that were examined under the microscope. For this purpose, a Zeiss microscope with Axio 


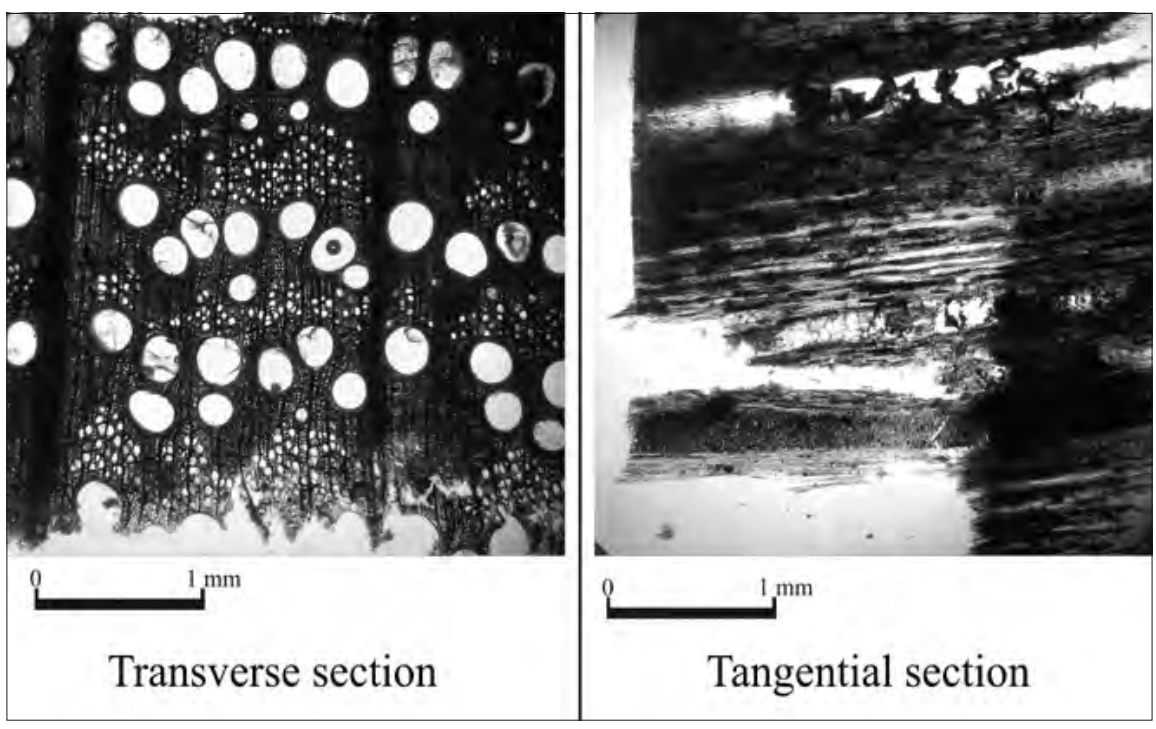

Fig. 4. A microscopic image of wood tissues from the coffin (photograph and prepared by J. Michalik).

Cam software was used, equipped with a Canon digital film camera and camera that were used to take photographs of the preparations, included in this paper. Thus obtained images of wood tissues were compared with tissue patterns from catalogues of F.H. Schweingruber (2011) and P. Greguss (1959), which allowed to identify the wood species.

The coffin in question was made of oak wood. Despite the small size of the samples and their considerable damage, it was possible to identify annual growth rings in cross and radial sections (Fig. 4). Based on this, the characteristic arrangement of tracheids and vessel elements could be compared with model preparations from the already mentioned catalogues.

Among the identified wood species from the twenty-five selected coffins from the Church of St. Nicholas, a vast majority were coniferous trees, mostly pines. Oak wood was only identified in five cases (Michalik 2018a: 53-59).

\section{Wire flowers from the coffin}

The coffin lid was decorated with eight artificial flowers, preserved in varying states. The collection included two types of three-leaf flowers, with slender, ellipsoidal petals - type I (Fig. 5, 6) and with round petals - type 2 (Fig. 7). The main frame of the petals was made of wire, O.I $\mathrm{mm}$ in diameter, with ends meeting at the base 


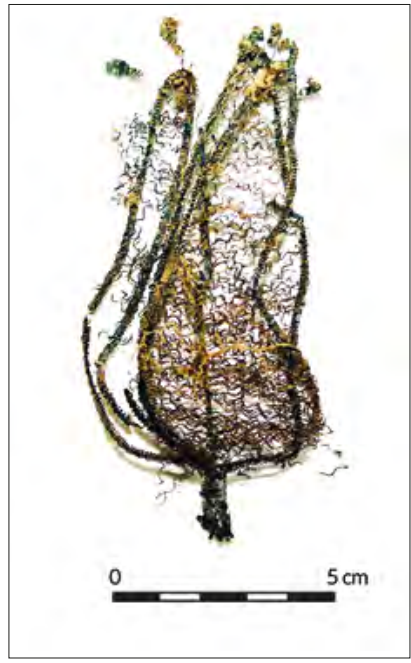

Fig. 5. A flower of the first type found on the coffin lid (photograph by D. Grupa).

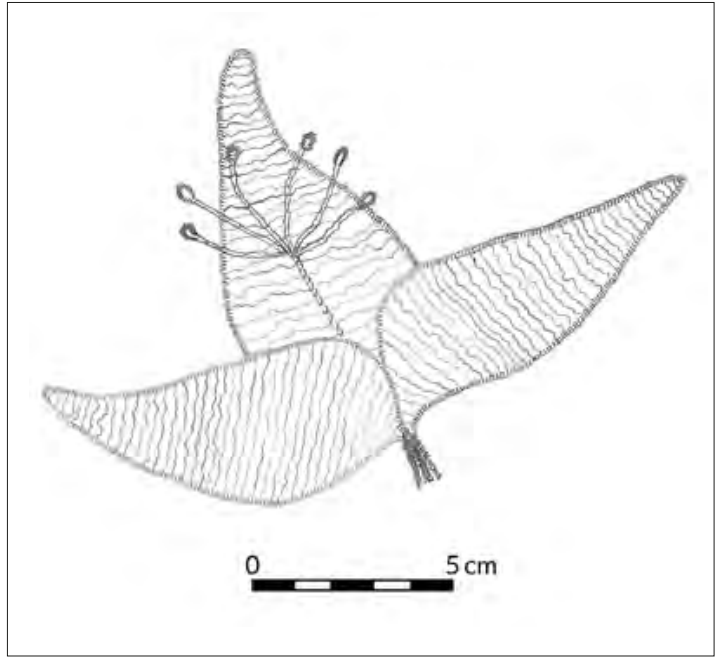

Fig. 6. A reconstruction drawing of a flower with ellipsoidal petals, opened (made by K. Kolaska).

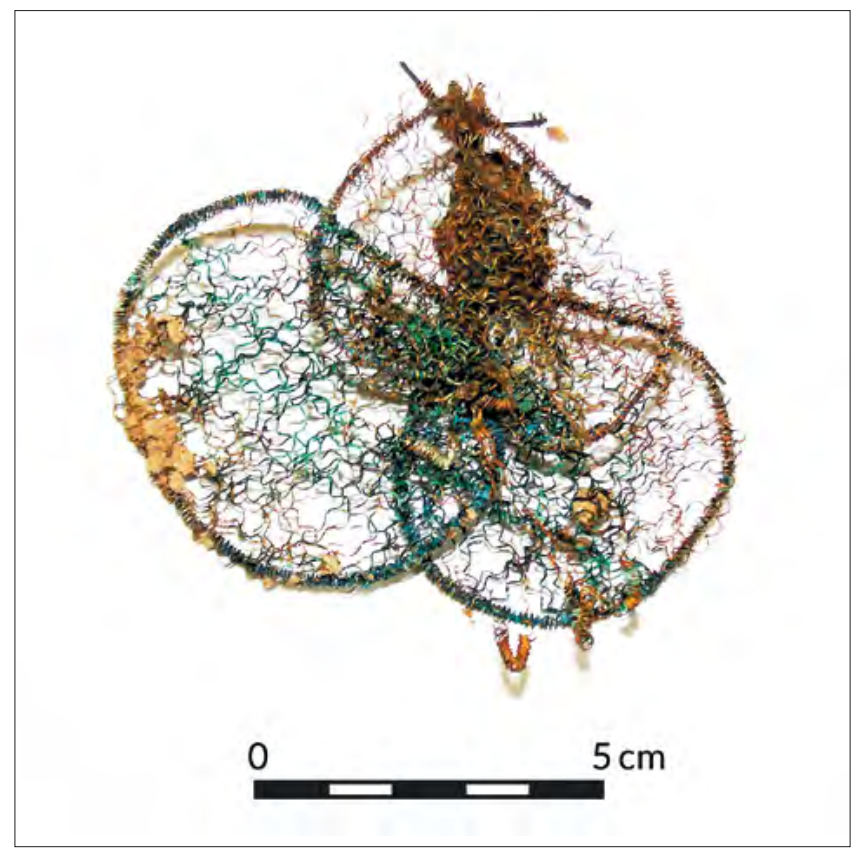

Fig. 7. A flower of the second type found on the coffin lid (photograph by D. Grupa). 
and twisted together, forming the stem. The wire on the edges of the petals was additionally decorated with tightly wound wire, also with diameter of o.I mm.

The central part of the petals was filled with parallel, slightly twisted wires, arranged crosswise, which most probably formed the basis for yarn or transparent silk gauze. Microscopic analyses performed revealed silk fibres entangled with the twisted wire.

Their total length, including ellipsoidal petals, was $113.9 \mathrm{~mm}$, and each petal was 95. $\mathrm{mm}$ long and $41.2 \mathrm{~mm}$ wide. The stem was $17.8 \mathrm{~mm}$ long, and between $4.4 \mathrm{~mm}$ and $6.3 \mathrm{~mm}$ in diameter. In the central part of the flower calyx, there were stamens of different length (max. $2.6 \mathrm{~mm}$, min. I.9 mm), made of spirally twisted wire.

The maximum width of a flower with round petals was $83.3 \mathrm{~mm}$, and its minimum width was $66.0 \mathrm{~mm}$. The petals were up to $52.5 \mathrm{~mm}$ long, and up to $52.0 \mathrm{~mm}$ wide. The stem was $22.7 \mathrm{~mm}$ long, and its diameter was between $6.2 \mathrm{~mm}$ and $4.6 \mathrm{~mm}$. In the middle part, there were nine stamens concentrated in two pistils, with four and five stamens respectively.

\section{Studs}

Metal studs could be found outside and inside the coffin. Despite considerable damage, three types of studs could be identified: decorative with a diameter of $13 \mathrm{~mm}$ and $\mathrm{is} \mathrm{mm}$, and plain, semi-circular, with a diameter of Io $\mathrm{mm}$ (Fig. 8). All studs were made of thin sheet of copper alloy, with thickness below i mm, onto which an iron shank was soldered. Such a combination of metals caused corrosion, which is why most studs were destroyed to a greater or lesser extent. In the case of isolated studs, complete partially-damaged shanks, covered with rust, were

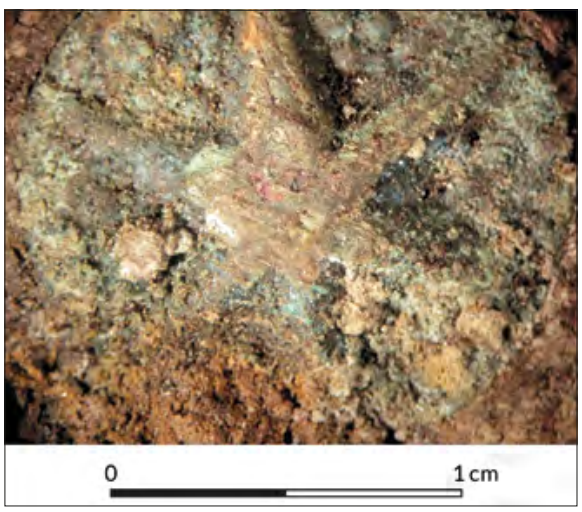

Fig. 8. A stud head detail (photograph by J. Michalik).

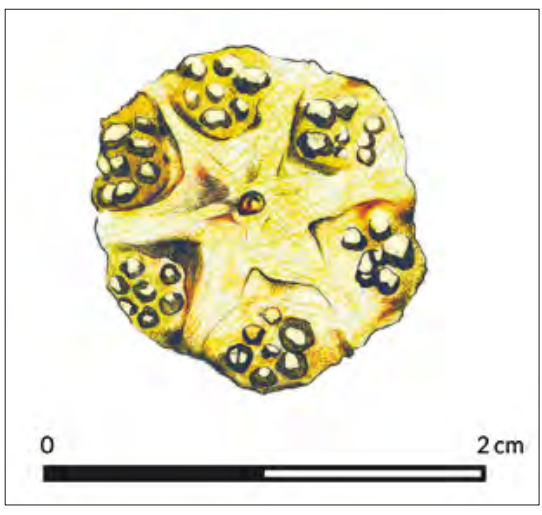

Fig. 9. A reconstruction drawing of a stud from the coffin (made by K. Kolaska). 
found, approx. $15 \mathrm{~mm}$ long, with a diameter of $2 \mathrm{~mm}$. The studs had probably been decorated before the shanks were attached. Their uniform coating indicates that they were made using a die in the shape of a six-pointed star, within which four to six, usually five, small 'dots' were punched, forming the shape of a simple flower calyx (Fig. 9). The irregular arrangement of the 'dots' allows to assume that they were made by hand after the shape of the star had been struck or that a few dies were used, with handmade 'dot' patterns.

\section{Analysis of the upholstery fabric}

During the initial stage of analysis of the coffin surface, no decorations apart from relics of metal flowers and studs were found. However, after microscopic analysis of the underside of the studs it turned out that there was fabric stuck to metal. And after corrosion had been gently removed, another fabric was discovered. The one closest to the stud surface was silk yarn, and the other was unmatted wool, plain-woven I/I (Fig. IO). It was also determined that the woollen fabric had been

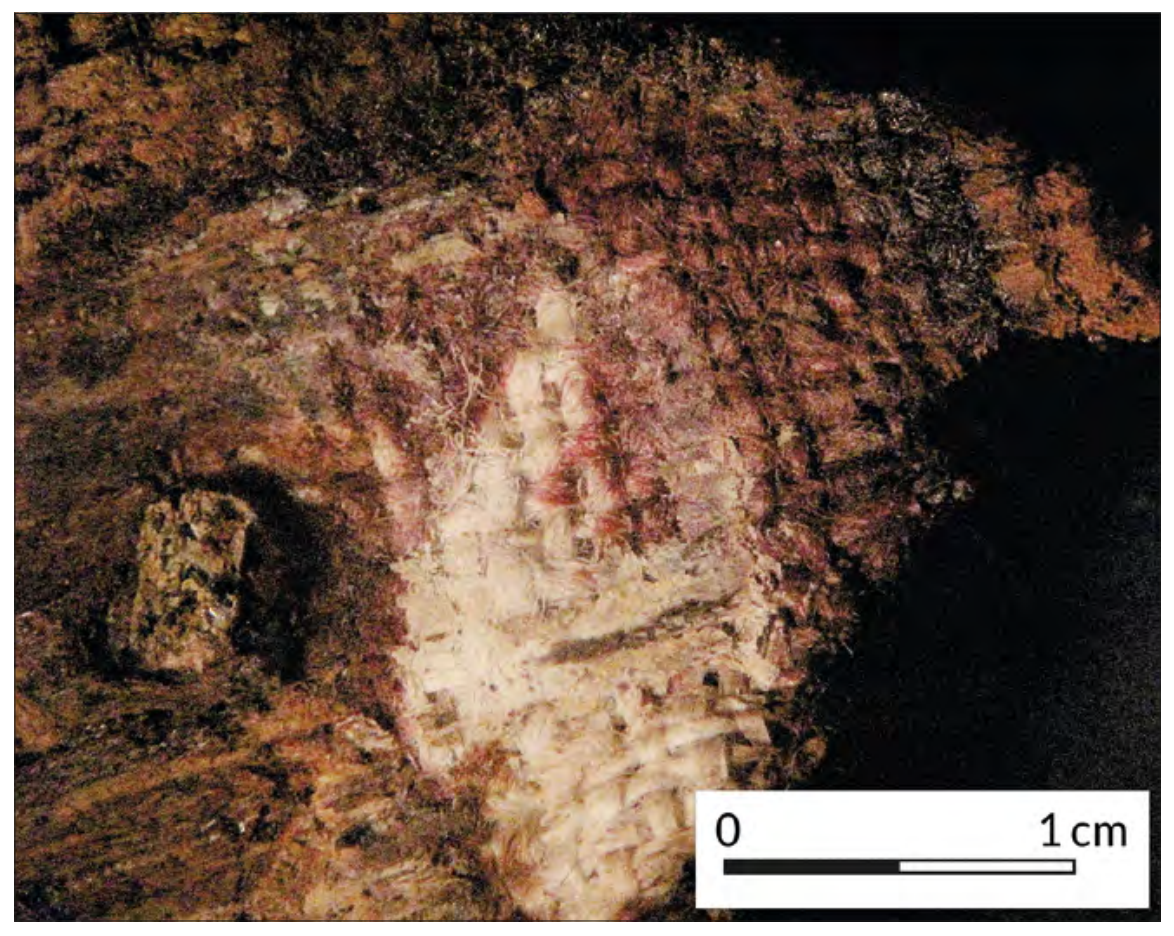

Fig. 10. Silk and woollen cloths found on the underside of a stud (photograph by J. Michalik). 

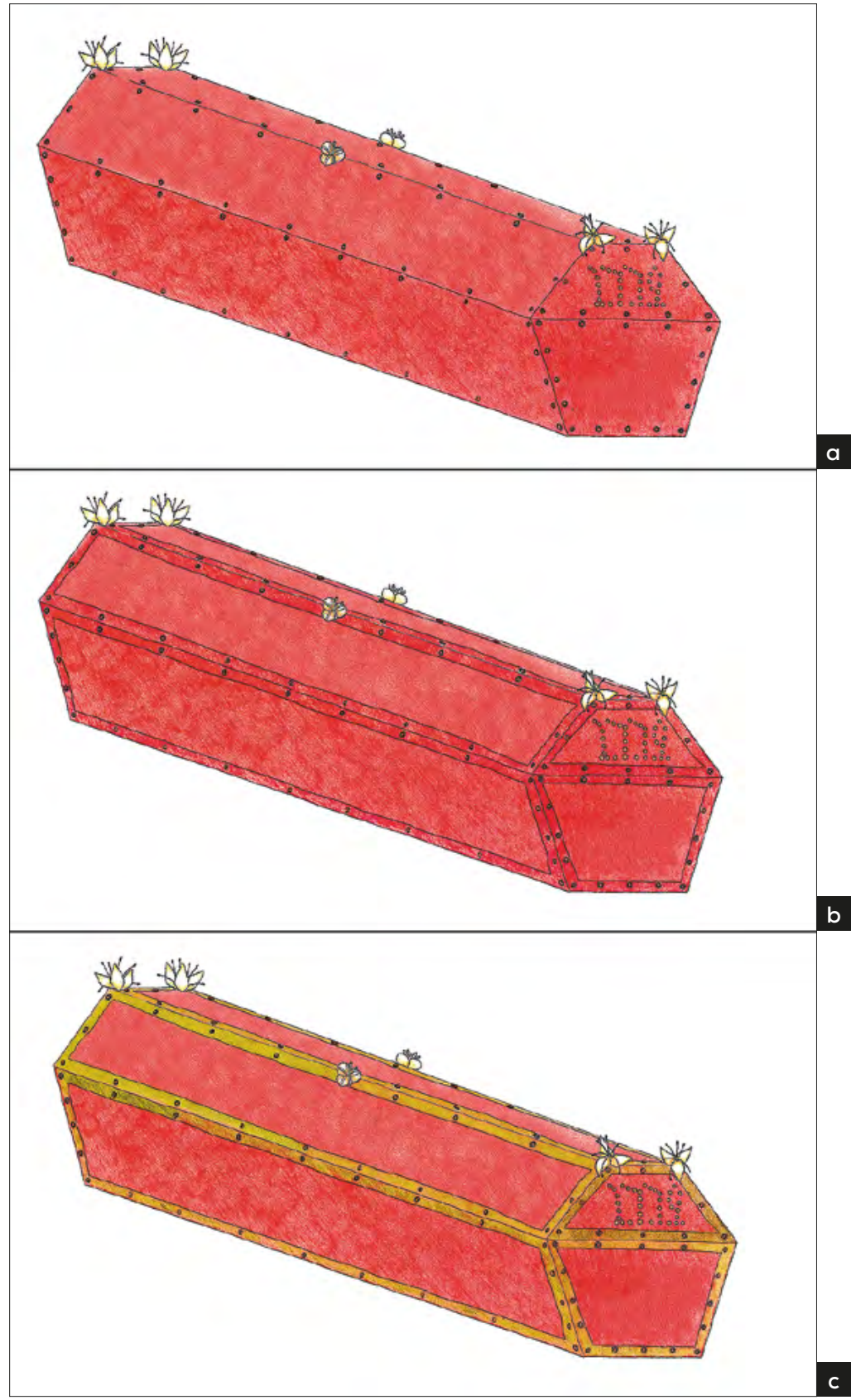

Fig. 11. Reconstruction of the probable appearance of the coffin: a) a variant without a tape; b) a variant with a red tape; c) a variant with a golden tape (by K. Kolaska). 
died red after weaving ${ }^{3}$. It is impossible to precisely recreate the original appearance of the coffin. Was it upholstered with two types of cloth or only wool, or is silk a relic of the tape along the edge of the woollen fabric that was attached to the wood with studs? Unfortunately, the scraps preserved only under the studs are not enough to determine the original state. The fabrics on the coffin were completely decomposed, just like those inside it. It can only be presumed that studs found inside the coffin were used to attach the internal upholstery fabric.

Decorating bodies and coffins with flowers was a common practice in the seventeenth and eighteenth centuries. Garlands of flowers were placed on the heads of the deceased, and bunches of flowers were put into their hands. The flowers could be only real, only artificial, or a combination of the two. In Gniew, all possible variants were identified during research (Grupa 2015: 48-51; Grupa et al. 2015: 117-120; Grupa, Nowak 2017: 160-168). Systematic analysis of the material provides some basis for general conclusions concerning artificial flowers in garlands and bunches. The flower structure was, to a large extent, based on wire of copper alloy imitating golden wire, twisted in the form of spirals with varying density, with individual elements attached. They seem to have been made based on some general rules in one workshop. However, flowers from the coffin dated 1779 were at least a hundred years younger than the ones found in the northern crypt. They did look magnificent, but they were definitely more modest compared with the older ones. It seems that it was not necessary to extend them as they were elements of a designed whole, which included upholstery fabrics on the outside and studs decorating the coffin edge. Artificial flowers, with their delicate openwork structure, served as an elegant complement to the whole (Fig. II, a, b, c). Figure II shows three possible variants of the coffin appearance during the funeral in 1779 .

\section{Conclusions}

Many instructions about funeral costs did not provide any information on flowers, neither artificial nor real. Only regulations of some of the cities suggest moderation (Grupa 2005: 72-73). In this case, however, they were clearly not observed. It was similar in the case of the funeral of August Michał Szczuka, son of Stanisław Antoni Szczuka, who died in 1702 and was buried in the crypt under the chancel of the Church of the Blessed Lady Mary in Szczuczyn. The cost of a funeral ceremony of a three-year-old amounted to PLN 405.35, which included candles, studs for the coffin ( 890 for PLN 46), fabrics as well as priests and other people performing

3 During research into woollen fabrics from Gdańsk it was noted that some of the matted fabrics were died after weaving. Analysis showed that outer and inner structures of the fabric were not uniformly saturated with dye (Grupa 20I2: IIO). It is similar in the case of the coffin upholstery fabric, even though it was not matted. 
the last offices. The high cost of this funeral is proved by a different bill issued a few years later in connection with the death of one of Szczuka's servants, which amounted to PLN 4I.48 (Grupa et al. 20I4b: 2I). It should be assumed that the cost of the funeral of the child from Gniew was similar to the cost of the funeral of young Szczuka, if not higher, as the studs were not plain but decorated with floral ornaments, which definitely increased their manufacturing costs.

It is believed that the most exclusive coffins were upholstered in whole. The richest were upholstered with silk (also on the inside), which was the most expensive cloth in the world at the time. The less wealthy were buried in more modest, yet still sumptuous, coffins upholstered with wool (Majorek, Grupa 2013: 80; Grupa et al. 20I4a: 166-18I). Moreover, the eighteenth-century coffins were usually painted on the outside ${ }^{4}$, and at the end of the century upholstering coffin lids was rare.

This was the first so richly ornamented child's coffin in archaeological research. If artificial flowers were used, they were included in bunches and garlands inside the coffin. In this case, all known coffin decorations were used, with value added by compositions of artificial flowers, the metal structure of which imitated golden wire. Another element that increased the burial cost was an oaken coffin. As already mentioned, most coffins from Gniew were made of pine boards, also known from other sites (Piaseczno, Szczuczyn, Radzyń Podlaski, and Łuków) 5 .

The child's coffin from Gniew was definitely more richly decorated than coffins of adults, including those found in the church crypt (Grupa et al. 2015: 35-38). There is no doubt that the child who died in 1779 and was buried in the coffin described in this paper had a sumptuous, worthy funeral organised by the family, celebrating all pompa funebris principles.

\section{Bibliography}

Chrościcki J. (1974), Pompa funebris. Z dziejów kultury staropolskiej, Państwowe Wydawnictwo Naukowe, Warszawa.

Dziubkowa J. (1993), Portret epitafijny i trumienny, [in:] J. Malinowski (ed.), Gdzie wschód spotyka Zachód. Portret osobistości dawnej Rzeczypospolitej 1576-1763. Katalog wystawy, Muzeum Narodowe, Warszawa, p. 35-40.

Greguss P. (1959), Holzanatomie der europäischen Laubhölzer und Sträucher, Akademiai Kiado, Budapest.

Grupa M. (2005), Ubiórmieszczan i szlachtyz XVI-XVIII wiekuz kościotap.w. Wniebowzięcia Najświętszej Marii Panny w Toruniu, Wydawnictwo Uniwersytetu Mikołaja Kopernika, Toruń.

4 Admittedly, painters attempted to give them the appearance of motifs used on silk, but these were modest representations resembling patterned silks, with fine designs that were to resemble floral ornaments - observations of the authors.

5 Analysis of the wood from the coffins is carried out by Jakub Michalik, and its results will be published in a separate paper. 
Grupa M. (20I2), Wetniane tekstylia pospólstwa i plebsu gdańskiego (XIV-XVII w.) i ich konserwacja, Wydawnictwo Naukowe Uniwersytetu Mikołaja Kopernika, Torun.

Grupa M. (2014), Problematyka konserwatorska zabytków wydobytych z nawarstwień podwodnych mostu zachodniego, [in:] A. Kola, G. Wilke (ed.), Wczesnośredniowieczne mosty przy Ostrowie Lednickim, vol. II, Mosty traktu poznańskiego (wyniki archeologicznych badań podwodnych prowadzonych w latach 1986-2003), Towarzystwo Autorów i Wydawców Prac Naukowych "Universitas", Kraków, p. 299-308.

Grupa M. (2015), Preliminary Analyses of Silk Flowers from Modern Graves in Poland, "Archaeological Textile Review", 57, p. 47-53.

Grupa M. (20I6), Koronki i wstażki - moda czy prestiż?, [in:] E. Wółkiewicz, M. Saczyńska, M.R. Pauk (ed.), Habitus facit hominem. Spoteczne funkcje ubioru $w$ średniowieczu i w epoce nowożytnej, Wydawnictwo Instytutu Archeologii i Etnologii Polskiej Akademii Nauk, Warszawa, p. 179-190.

Grupa M., Drążkowska A. (2OI4), Kilka uwag na temat koronek klockowych z odzieży grobowej, [in:] M. Bis, W. Bis (ed.), Rzeczy i ludzie. Kultura materialna w późnym średniowieczu i w okresie nowożytnym, Wydawnictwo Instytutu Archeologii i Etnologii Polskiej Akademii Nauk, Warszawa, p. 325-333.

Grupa M., Łukaszewicz J.W. (2019), Silk Band and Metal Appliqués of a Child's Bonnet From the Northern Crypt of the Parish Church in Gniew. Jedwabna wstazka i metalowe aplikacje z dziecięcego czepka z krypty pótnocnej kościoła parafialnego w Gniewie, "Analecta Archaeologica Ressoviensia", I4, p. I37-I53, https://doi.org/IO.I5584/anarres.2019.I4.IO

Grupa M., Nowak M. (2018), Wianki jako element wyposażenia grobowego, "Acta Universitatis Nicolai Copernici Archeologia", 35, p. I59-172.

Grupa M., Warecka O. (20I7), Wybrane różańce z badań w kościele parafialnym pw. św. Mikotaja w Gniewie, "Rydwan", I3, p. 3I-42.

Grupa M., Grupa D., Majorek M. (20I4a), Selected Silk Coffin Upholstery From I7 ${ }^{\text {th }}$ and $8^{\text {th }}$ Centuries on Polish Lands. Wybrane jedwabne obicia trumien $z$ XVII $i$ XVIII wieku na ziemiach polskich, "Sprawozdania Archeologiczne", 66, p. I65-182.

Grupa M., Grupa D., Kozłowski T., Krajewska M., Majorek M., Nowak M., Nowak S., Przymorska-Sztuczka M., Wojciechowska A., Dudziński T. (20I4b), Tajemnice szczuczyńskich krypt, vol. II, Towarzystwo Przyjaciół 9 PSK. Uniwersytet Mikołaja Kopernika, Grajewo-Toruń.

Grupa M., Kozłowski T., Jankauskas R., Grupa D., Krajewska M., Krakowska S., Majorek M., Mosiejczyk J., Nowak M., Nowak S., Przymorska-Sztuczka M., Wojciechowska A. (20I5), Secrets of the Crypt in St. Ann's Chapel. Tajemnice krypty w kaplicy św. Anny, Stowarzyszenie Centrum Aktywnych, Gniew.

Grupa D., Grupa M., Kozłowski T., Krajewska M., Majorek M., Nowak M., Wojciechowska A. (2016a), Badania w kościele pw. św. Mikotaja w Gniewie w latach 2009-20Io, [in:] M. Fudziński (ed.), I Pomorska Sesja Sprawozdawcza, Muzeum Archeologiczne, Gdańsk, p. IO3-II4.

Grupa M., Grupa D., Krajewska M., Majorek M., Kozłowski T. (20I6b), Jedwab, koronki i choroby transmisyjne świadectwem kontaktów handlowych Gniewu z Europa, [in:] M. Wardas-Lasoń (ed.), Nawarstwienia historyczne miast Europy Środkowej, Wydawnictwa AGH, Kraków, p. 385-395. 
Kizik E. (1998), Śmierć w mieście hanzeatyckim w XVI-XVIII wieku. Studium z nowożytnej kultury funeralnej, Wydawnictwo Uniwersytetu Gdańskiego, Gdańsk.

Klint P., Rzemieniecki K., Węglorz J. (2018), Źródta szlacheckie z ksiag grodzkich i ziemskich ziemi halickiej z XVII wieku, Wydawnictwo Uniwersytetu Wrocławskiego, Wrocław.

Majorek M., Grupa D. (2013), Malowane czy obijane - oznaka mody czy potrzeby na przyktadzie trumien z krypt kościota w Szczuczynie (cz. I), [in:] M. Grupa, T. Dudziński (ed.), Tajemnice szczuczyńskich krypt. Materiaty z konferencji naukowej Szczuczyn - 2I IX 2013 r., Towarzystwo Przyjaciół 9 PSK, Grajewo, p. 69-8I.

Majorek M., Grupa D. (20I4), Wybrane nowożytne pasamony z krypty potudniowej kościota pod wezwaniem św. Mikotaja w Gniewie, [in:] M. Bis, W. Bis (ed.), Rzeczy i ludzie. Kultura materialna w późnym średniowieczu i w okresie nowożytnym. Studia dedykowane Marii Dąbrowskiej, Wydawnictwo Instytutu Archeologii i Etnologii Polskiej Akademii Nauk, Warszawa, p. 335-348.

Majorek M., Grupa D. (2016), Child Burial Wreaths in Early Modern Royal Prussia, [in:] J. Kodzik, W. Zientara (ed.), Hybride Identitäten in den preussisch-polnischen Stadtkulturen der Aufklärung. Studien zur Aufklärungsdiffusion zwischen Stadt und Land, zur Identitätsbildung und zum Kulturaustausch in regionalen und internationalen Kommunikationsnetzwerken, Lumière, Bremen (Presse und Geschichte. Neue Beiträge, 99), p. 163-I72.

Michalik J. (2018a), Identyfikacja gatunku drewna archeologicznego na przyktadzie wybranych trumien odkrytych podczas badan archeologicznych w kościele pw. św. Mikotaja w Gniewie, "Rydwan", I3, p. 53-59.

Michalik J. (20I8b), Medaliki z wizerunkiem świętego Ignacego Loyoli pochodzace z badań archeologicznych $w$ kościele pw. św. Mikotaja w Gniewie, "Rydwan", I3, p. 60-67.

Nowosad W., Kowalkowski J. (20I6), Testamenty szlachty Prus Królewskich z XVII wieku, Wydawnictwo DiG, Warszawa.

Schweingruber F.H. (20II), Anatomie europäischer Hölzer - Anatomy of European Woods, Verlag Kessel, Remagen-Oberwinter.

\section{Summary}

Rich or Modest - Analysis and Reconstruction of the Appearance of a Child's Coffin from 1779 from the Church of St. Nicholas in Gniew (Pomerania Province, Poland)

Research conducted in churches provides more and more information about the funeral culture in the Baroque. The basic elements of a funeral were wooden coffins, in which bodies were buried. They were prepared for the funeral in different ways. The simplest were ordinary boxes made of planed boards. What draws attention, however, are those with additional elements on the outside. This child's coffin found in the central nave between the chancel and the first pillar was decorated with artificial flowers made of wire imitating golden wire. These flowers drew the attention of the research team to the unique ornamentation of the coffin. The next stage of the work involved cleaning the studs found (three types), and then analysing the unusual structures on their underside. This revealed two types of cloth stuck to metal. All the information gathered allowed to 
prepare three variants of the appearance of the coffin with the year 1779 studded with one of the stud types. Considering the above, it was concluded that the child's burial was rich, and that the coffin decorations were exceptionally sumptuous.

Keywords: coffin, artificial flowers, church, modern era, Gniew

\section{Streszczenie}

\section{Bogata czy uboga - analiza i rekonstrukcja wyglądu dziecięcej trumny z 1779 roku z kościoła pw. św. Mikołaja w Gniewie (woj. pomorskie, Polska)}

Badania prowadzone w kościołach dostarczają coraz więcej informacji na temat kultury funeralnej okresu baroku. Jednym z podstawowych elementów samego pogrzebu są drewniane trumny, w których składano ciała. Były one w bardzo różny sposób przygotowywane do ceremonii pogrzebowej. Najprostsze to zwykła skrzynka wykonana z obrobionych desek. Uwagę jednak zwracają te z dodatkowymi elementami na powierzchni. Dziecięca trumna znajdująca się w nawie głównej pomiędzy prezbiterium a pierwszym filarem była ozdobiona sztucznymi kwiatami wykonanymi z drutu imitującego pierwotnie złoty. I to właśnie te kwiaty zwróciły uwagę ekipy badawczej na unikatowe zdobienie trumny. Kolejnym etapem prac było oczyszczenie znalezionych ćwieków (były ich trzy rodzaje), a następnie analiza dziwnych struktur znajdujących się po lewej stronie. W wyniku tych czynności ujawniono dwa rodzaje tkanin przylegających do metalu. Wszystkie odkryte informacje pozwoliły na przygotowanie trzech wariantów wystroju powierzchni trumny z datą 1779 nabitą jednym z rodzajów ćwieków. W świetle tych przesłanek stwierdzono, że pochówek dziecka należał do bogatych, a wystrój trumny do wyjątkowo bogatych.

Słowa kluczowe: trumna, sztuczne kwiaty, kościół, epoka nowożytna, Gniew

\section{Karolina Kolaska}

Nicolaus Copernicus University in Toruń

Institute of Archaeology

Poland

e-mail: karolinamariakolaska@gmail.com

\section{Jakub Michalik}

Nicolaus Copernicus University in Toruń

Institute of Archaeology

Poland

e-mail: michalik@doktorant.umk.pl

\section{Małgorzata Grupa}

Nicolaus Copernicus University in Toruń

Institute of Archaeology

Poland

e-mail: mgrupa@umk.pl 